\title{
CARTA DE AUTORIZAÇÃO PARA PUBLICAÇÃO E CONCESSÃO DE DIREITOS AUTORAIS
}

Ernandes Gonçalves Dias. Rua Maria Alves da Silva, № 58, Icaraí, Monte Azul-MG, CEP: $39500-$ 000. RG: MG-14.885.492 - CPF: 082.218.096-08, doravante denominado Autor Responsável, elaborou o original do artigo "ESTRESSE OCUPACIONAL EM TRABALHADORES DE UMA AUTOESCOLA DE JANAÚBA, MINAS GERAIS", juntamente com a autora: Maria Luiza Silva Faria, e por serem titulares da propriedade literária do mesmo e em condições de autorizarem a edição de seu trabalho, concedem à Revista UniVap On-line - Conselho Editorial permissão para comercializar, editar e publicar o citado artigo na versão online (ISSN 2237-1753), em número e volume ainda a serem definidos pelo Conselho Editorial da revista. Essa concessão não terá caráter de ônus algum para o Conselho Editorial da Revista UniVap On-line, ou seja, não será necessário o pagamento em espécie alguma pela utilização do referido material, tendo o mesmo o caráter de colaboração. Os Autores comprometem-se a assegurar o uso e gozo da obra à Revista UniVap On-line, - Conselho Editorial, que poderá explorá-la com exclusividade nas edições que fizer e comprometem-se também a não autorizarem terceiros a transcreverem ou traduzirem parte ou totalidade da obra sem expressa autorização do Conselho Editorial da revista, cabendo ao infrator as penas da legislação em vigor.

Os autores declaram ainda não haver qualquer conflito de interesse relacionado a divulgação deste trabalho.

Os autores do presente trabalho se comprometem a cumprir as seguintes normas:

1) Todos os autores relacionados acima participaram do trabalho e responsabilizam-se publicamente por ele.

2) Todos os autores revisaram a forma final do trabalho e o aprovam para publicação na Revista UniVap On-line,.

3) Este trabalho, ou outro substancialmente semelhante em conteúdo, não foi publicado, nem está sendo submetido a outro periódico ou foi publicado como parte de livro.

4) Os autores concordam em ceder os direitos autorais do artigo à Revista UniVap On-line, e a reprodução total ou parcial do mesmo em outras publicações requer a autorização por escrito .

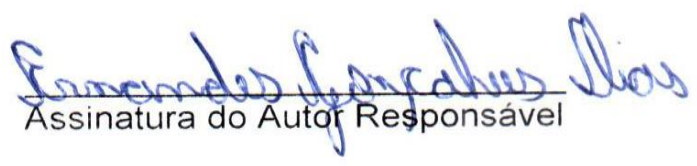

